Supporting Information

\title{
Reversible Thermochromic Nanoparticles Composed of Eutectic Mixture for Temperature controlled Photothermal Therapy
}

Song Shen,,$^{\dagger}{ }^{*}$ Lei Feng,,$^{\dagger}$ Shunyao Qi, / Jin Cao,,$^{\dagger}$ Yanru Ge,,$^{\dagger}$ Lin Wu,,,${ }^{*}$ and Shu Wang $, \dot{t}, *$

$\dagger$ College of Pharmaceutical Sciences, Jiangsu University, Zhenjiang, Jiangsu 212013, China

* Beijing National Laboratory for Molecular Sciences, Key Laboratory of Organic Solids, Institute of Chemistry, Chinese Academy of Sciences Beijing 100190, China

$\S$ Affiliated Hospital of Jiangsu University, Zhenjiang 212001, China

" China Pharmaceutical University, Nanjing 210000 (China) 


\section{METHODS}

\section{Materials}

2-Naphthol, Bisphenol A (BPA), Indocyanine green (ICG) and polyethylene glycol (PEG, $\mathrm{Mw}=4000)$ were purchased from Sinopharm Chemical Reagent Co., Ltd. Hoechst 33342, 3-[4,5dimethylthialzol-2-yl]-2,5-diphenyltetrazolium bromide (MTT) were obtained from SigmaAldrich. 2-phenylamino-3-methyl-6-dibutyl amino fluoran (TFG) was obtained from Changshu Dyestuff Chemical Factory (China). LysoGreen, calcein AM and propidium iodide was purchased from Thermo Fisher. All chemicals were used without purification. Deionized water (18.4 $\mathrm{M} \Omega$ $\mathrm{cm}$ ) used in all experiments was prepared by the Milli-Q system (Millipore, USA).

\section{Preparation of reversible thermochromic nanoparticles}

Reversible thermochromic nanoparticles were prepared by dispersing the molten thermochromic mixture (leuco dye, developer and solvent) into water. Typically, the mixture of TFG:Naph:PEG=1:5:150 was heated at $80{ }^{\circ} \mathrm{C}$ for $30 \mathrm{~min}$ to obtain a clear molten liquid. Then, the melted thermochromic mixture was dropwise added into water or serum at room temperature (RT). Afterwards, uniform green solution with opalescence was formed after stirring for 2 min.

\section{Characterizations of reversible thermochromic nanoparticles}

The thermochromic nanoparticles were negatively stained with $1 \%$ phosphotungstic acid for transmission electron microscopy (TEM) characterization (JEOL JEM-2100HR). The particle size distribution was measured at RT by dynamic light scattering (DLS, Zetasizer Nano ZS, Malvern). 
The absorbance of the nanoparticles was measured by UV/vis spectrophotometer (PerkinElmer, Lambda35). Differential scanning calorimetry (DSC, Netzsch) was used to test the thermal properties of TFG, BPA, Naph and PEG. Samples were heated at a rate of $10{ }^{\circ} \mathrm{C}$ per min in a

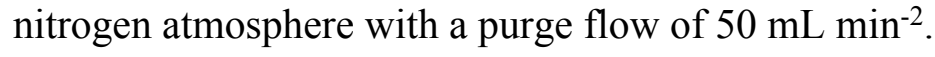

\section{Photothermal effect measurement}

The photothermal effect of reversible thermochromic nanoparticles was evaluated using a $660 \mathrm{~nm}$ laser at a power density of $2 \mathrm{~W} \mathrm{~cm}^{-2}$. These nanoparticles solutions with serious concentrations (at TFG dose) of $0,100,200,400 \mu \mathrm{g} \mathrm{mL}-1$ were irradiated for $10 \mathrm{~min}$ and the temperature of the solutions was measured by a thermocouple thermometer at intervals of $1 \mathrm{~min}$

for total 10 minutes. Meanwhile, the temperature was also recorded by Infrared Thermal Camera (FLIR ThermaCAM S65). The photothermal effect of ICG was evaluated by irradiation of an 808 $\mathrm{nm}$ laser at a power density of $2 \mathrm{~W} \mathrm{~cm}^{-2}$.

To determine the photothermal conversion efficiency, the temperature change of the thermochromic nanoparticles aqueous solution was measured as the irradiation time prolonged $\left(660 \mathrm{~nm}, 2 \mathrm{~W} \mathrm{~cm}^{-2}\right.$, for $5 \mathrm{~min}$ ). Then the heated aqueous dispersion was cooled down naturally and the temperatures were carefully monitored every $20 \mathrm{~s}$ using a thermometer with a thermocouple probe during the cooling process. The photoconversion efficiency $(\eta)$ was calculated by the following equation:

$$
\eta=\frac{h s\left(T_{\max }-T_{\text {surr }}\right)-Q_{\text {dis }}}{I\left(1-10^{-A 660}\right)}(1)
$$


$\eta$ is the conversion efficiency from the $660 \mathrm{~nm}$ laser energy to thermal energy, $\mathrm{h}$ is the heat conversion efficiency, $\mathrm{s}$ is the surface area of the container, and $\mathrm{T}_{\max }$ and $\mathrm{T}_{\text {surr }}$ are the equilibrium temperature and the ambient temperature of the surrounding respectively. $I$ is the incident laser power $(0.5 \mathrm{~W})$, and $\mathrm{A}_{660}$ is the absorbance $(0.12)$ of the Naph NPs solution at the wavelength of $660 \mathrm{~nm}$. In addition, $\mathrm{Q}_{\text {dis }}$ expresses the heat dissipation by the test cell. In order to calculate $\eta$, all the parameters are known in Eq. (1) except $h s$, which need to be deduced.

In order to deduce $h s$, a dimensionless driving force temperature $\theta$ and a time constant $\tau_{\mathrm{s}}$ are introduced in Eq. (2) and Eq. (3):

$$
\begin{aligned}
\theta & =\frac{T-T_{\text {surr }}}{T_{\text {max }}-T_{\text {surr }}}(2) \\
\tau_{S} & =\frac{\sum_{i} m_{i} C_{p, i}}{h s}(3)
\end{aligned}
$$

where $\mathrm{m}$ is the mass $(0.15 \mathrm{~g})$ and $\mathrm{Cp}$ is the heat capacity $\left(4.2 \mathrm{~J} / \mathrm{g} \cdot{ }^{\circ} \mathrm{C}\right)$. The time constant $(\tau s)$ is derived from the slope of cooling period time t versus $\ln \theta$ graph and can be calculated using Eq.

$$
\mathrm{t}=-\tau_{s} \ln (\theta)
$$

Light transmission depth was performed by irradiating the ICG $\left(400 \mu \mathrm{g} \mathrm{mL}^{-1}\right)$ and TFG/Naph NPs (at TFG dose of $400 \mu \mathrm{g} \mathrm{mL}^{-1}$ ) solutions from the top of the vials using $808 \mathrm{~nm}$ and $660 \mathrm{~nm}$ laser at a power density of $2 \mathrm{~W} \mathrm{~cm}^{-2}$, respectively (Figure 3c). During the irradiation, the transmitted light was filmed from lateral of the vial using a digital camera. Meanwhile, the temperature was recorded by infrared thermal camera.

\section{Photothermal stability and release of TFG from the thermochromic nanoparticles}


The stability of TFG/Naph NPs was studied by using ICG as control. The ICG $\left(50 \mu \mathrm{g} \mathrm{mL}^{-1}\right)$ and TFG/Naph NPs $(50 \mu \mathrm{g} \mathrm{mL}-1)$ solutions was heated to $45^{\circ} \mathrm{C}$ by adjusting the laser power density and then cooled down to RT. The solutions were heated and cooled for five cycles.

Release of TFG from TFG/Naph NPs was evaluated by heating the solution $\left(400 \mu \mathrm{gL}^{-1}, 10\right.$ $\mathrm{mL})$ at $50{ }^{\circ} \mathrm{C}$ for $1 \mathrm{~h}$. At indicated time points, $1 \mathrm{~mL}$ of the solution was retrieved and $1 \mathrm{~mL}$ of fresh water was supplemented. The collected solution was centrifuged at 13,000 r/min for $20 \mathrm{~min}$. After centrifugation, $0.75 \mathrm{~mL}$ of the supernatant was taken and mixed with $0.1 \mathrm{~mL}$ of citric acid solution $\left(50 \mathrm{mg} \mathrm{mL}^{-1}\right)$ and $2.15 \mathrm{~mL}$ of $50 \%$ ethanol solution for UV-vis absorbance measurement $(620 \mathrm{~nm})$. The TFG release percentage was calculated by $\left(A_{t}-A_{0}\right) /\left(A_{100}-A_{0}\right) \times 100$, where $A_{t}$ is the absorbance of the solution at the indicate time point, $\mathrm{A}_{0}$ is the initial absorbance of the solution before heating, and $\mathrm{A}_{100}$ is the absorbance of TFG at the initial concentration (without centrifugation).

\section{Cell culture}

MCF-7 (human breast carcinoma cell line) and S180 (mouse ascites tumor cell line) cells were cultured in RPMI 1640 (Gibco, U.S.A.) supplemented with 10\% (v/v) fetal bovine serum (Sijiqing Biologic, China), penicillin $\left(100 \mathrm{U} \mathrm{mL}^{-1}\right)$ and streptomycin $\left(100 \mathrm{U} \mathrm{mL}^{-1}\right)$ at $37^{\circ} \mathrm{C}$ in the humidified atmosphere with $5 \% \mathrm{CO}_{2}$. Cells were subcultured regularly using trypsin/EDTA.

\section{Cellular uptaken}


For cell uptake experiments, IR780 labeled nanoparticles (IR780/Naph NPs) were prepared using a modified method that the TFG was replaced with IR780 while other conditions kept the same as TFG/Naph NPs. MCF-7 cells were seeded into 6-well plates with a density of $2 \times 10^{5}$ cells per well and cultured overnight. The IR780/Naph NPs (IR780=10 $\mu \mathrm{M})$ were incubated with the cells at $37{ }^{\circ} \mathrm{C}$ for $2 \mathrm{~h}$. After washing for 3 times, the cells were stained with Hoechst 33342 (10 $\mu \mathrm{g} / \mathrm{mL})$ and Lysotracker Green $(1 \mu \mathrm{M})$ in RPMI 1640 at $37^{\circ} \mathrm{C}$ for $20 \mathrm{~min}$. After washing with PBS for 3 times, the cells were observed using a Zeiss LSM800 confocal microscope.

\section{Cytotoxicity and photothermal toxicity evaluation}

The cytotoxicity of the TFG/Naph NPs was evaluated on MCF-7 cells. MCF-7 cells were seeded into 96 -well plates with a density of $5 \times 10^{3}$ cells per well and cultured overnight. Then, TFG/Naph NPs solutions with serious concentrations were added and incubated with cells for 24 h. A standard cell viability assay using 3-(4,5-dimethylthiazol-2-yl)-2,5- diphenyltetrazolium bromide (MTT) was conducted to determine the cell viability. To evaluate the photothermal toxicity, TFG/Naph NPs and ICG were incubated with cells for $0.5 \mathrm{~h}$ and then irradiated with 660 $\mathrm{nm}$ and $808 \mathrm{~nm}$ laser at a power density of $2 \mathrm{~W} \mathrm{~cm}^{-2}$ for $5 \mathrm{~min}$, respectively. Afterwards, the cell availability was determined by MTT assay.

We also evaluated the photothermal toxicity by live/dead cells staining. Cells in 24-well plate

were incubated with ICG $\left(50 \mu \mathrm{g} \mathrm{mL}^{-1}\right)$ and TFG/Naph NPs $\left(50 \mu \mathrm{g} \mathrm{mL} \mathrm{L}^{-1}\right)$ for $4 \mathrm{~h}$ and then irradiated with $660 \mathrm{~nm}$ and $808 \mathrm{~nm}$ laser at a power density of $2 \mathrm{~W} \mathrm{~cm}^{-2}$ for $5 \mathrm{~min}$, respectively. After double 
staining with calcein AM $(1 \mu \mathrm{M})$ and propidium iodide $(1 \mu \mathrm{M})$ for $20 \mathrm{~min}$. The cells were imaged with Zeiss LSM800 confocal microscope.

\section{Photothermal Therapy in vivo}

ICR mice were obtained from Yangzhou University. All animal procedures were approved by Animal Ethics Committee of Jiangsu University. After developing S180 subcutaneous tumors for about 5 days (with tumor volume of $100 \mathrm{~mm}^{3}$ ), different treatments were applied: a) PBS (200 $\mu \mathrm{L})$, b) PBS (200 $\mu \mathrm{L})+$ Laser, c) ICG $\left(4 \mathrm{mg} \mathrm{kg}^{-1}\right)$, d) ICG (4 mg kg-1) + Laser, e) TFG/Naph NPs (at a TFG dose of $4 \mathrm{mg} \mathrm{kg}^{-1}$ ), f) TFG/Naph NPs (at a TFG dose of $4 \mathrm{mg} \mathrm{kg}^{-1}$ ) + Laser. At $3 \mathrm{~h}$ post intravenous injection, tumors in the laser groups were exposed to NIR light for $5 \min \left(2 \mathrm{~W} \mathrm{~cm}^{-2}\right)$. The treatment was conducted every two days for total 3 times. The therapeutic temperature during the therapy was recorded by an infrared thermal camera. Tumor size was measured every two days for total 14 days. The tumor volume was defined as: volume $=\mathrm{L} \times \mathrm{W}^{2} / 2$, where, $\mathrm{L}$ and $\mathrm{W}$ represent maximum length and width, respectively. Relative tumor volumes were obatined using the formula: $\mathrm{V} / \mathrm{V}_{0}\left(\mathrm{~V}_{0}\right.$ was the initial tumor volume). After therapy, all the mice were euthanized and the major tissues were harvested. H\&E staining was subsequently performed to observe the therapeutic effect. 
Table S1. The melting point of thermochromic mixture (TFG/Naph/PEG) with different ratios.

\begin{tabular}{cc}
\hline TFG:Naph:PEG & m.p. $\left({ }^{\circ} \mathrm{C}\right)$ \\
$1: 5: 5$ & 33.2 \\
$1: 5: 10$ & 38.9 \\
$1: 5: 11$ & 41.8 \\
$1: 5: 12$ & 42 \\
$1: 5: 13$ & 43.4 \\
$1: 5: 14$ & 44.9 \\
$1: 5: 15$ & 45.4 \\
$1: 5: 20$ & 50.4 \\
$1: 5: 30$ & 53.9 \\
$1: 5: 40$ & 54.5 \\
$1: 5: 50$ & 55.3 \\
$1: 5: 60$ & 56.7 \\
$1: 5: 90$ & 57.7 \\
$1: 5: 120$ & 58.8 \\
$1: 5: 150$ & 58.9 \\
$1: 5: 200$ & 59.1 \\
\hline
\end{tabular}


Table S2. The melting point of thermochromic mixture (TFG/BPA/PEG) with different ratios.

\begin{tabular}{|c|c|}
\hline TFG:BPA:PEG & m.p. $\left({ }^{\circ} \mathrm{C}\right)$ \\
\hline $1: 5: 5$ & 42.3 \\
\hline $1: 5: 10$ & 43.4 \\
\hline $1: 5: 11$ & 44.9 \\
\hline $1: 5: 12$ & 46.4 \\
\hline $1: 5: 13$ & 48.8 \\
\hline $1: 5: 14$ & 50.8 \\
\hline $1: 5: 15$ & 51.9 \\
\hline $1: 5: 20$ & 53.2 \\
\hline $1: 5: 30$ & 57.7 \\
\hline $1: 5: 40$ & 58 \\
\hline $1: 5: 50$ & 58.1 \\
\hline $1: 5: 60$ & 58.2 \\
\hline $1: 5: 90$ & 58.4 \\
\hline $1: 5: 120$ & 58.6 \\
\hline $1: 5: 150$ & 58.8 \\
\hline $1: 5: 200$ & 59 \\
\hline
\end{tabular}




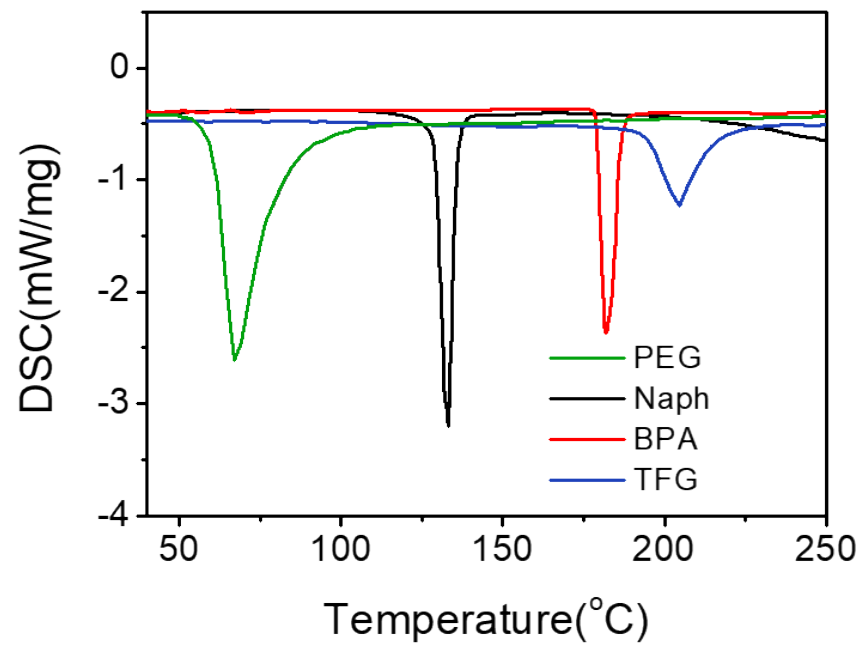

Figure S1. Differential scanning calorimetry (DSC) curves of PEG, Naph, BPA and TFG in the temperature range of $40-250{ }^{\circ} \mathrm{C}$. 


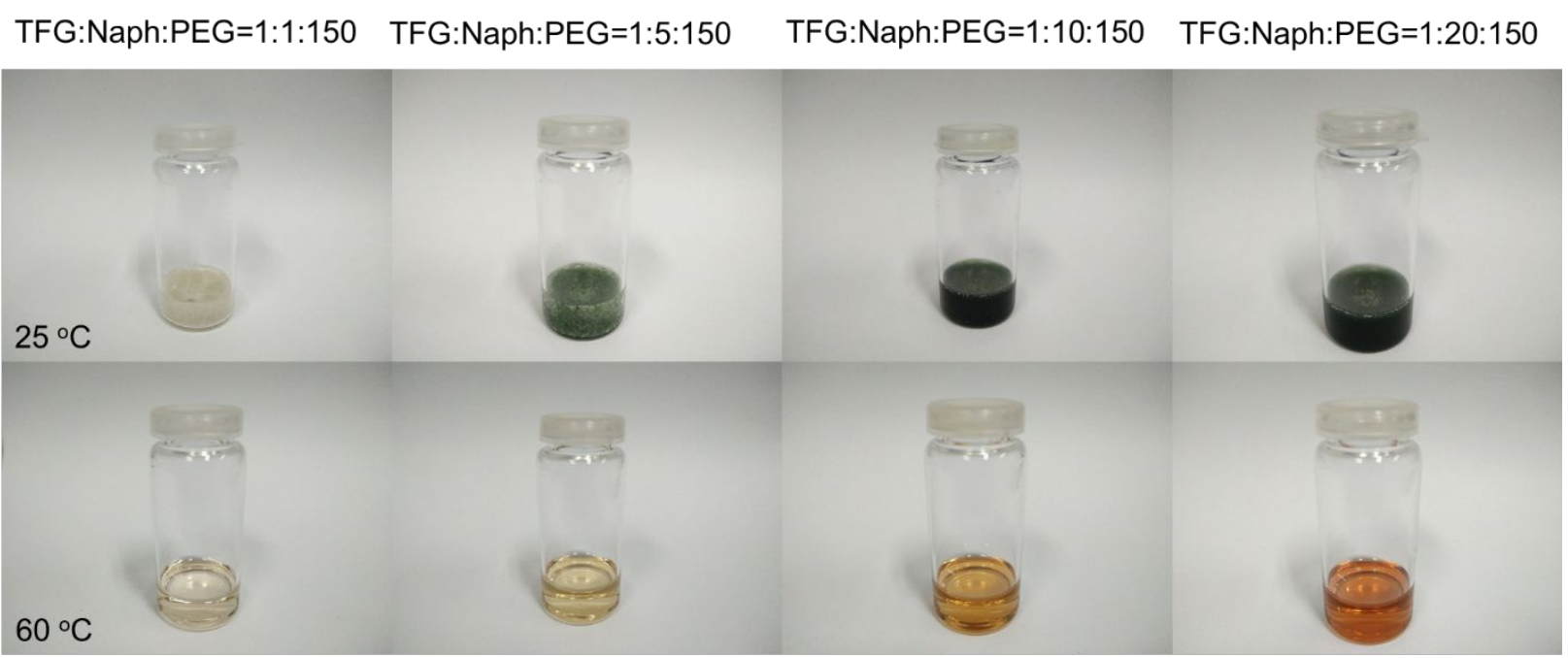

Figure S2. Digital photographs of thermochromic complex with TFG:Naph:PEG of different ratios at $25{ }^{\circ} \mathrm{C}$ and $60{ }^{\circ} \mathrm{C}$ showing the thermochromic property. 

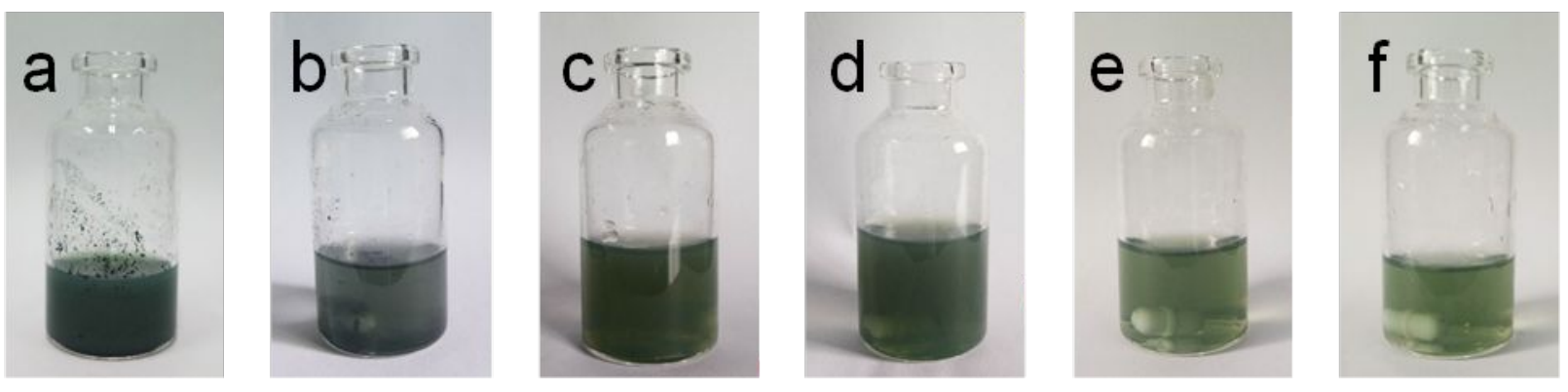

Figure S3. Digital photographs of TFG/Naph NPs with different ratios of PEG, TFG:Naph:PEG=1:5:30 (a), 1:5:60 (b), 1:5:90 (c), 1:5:120 (d), 1:5:150 (e), 1:5:200 (f). 
A $\quad 25^{\circ} \mathrm{C} \quad 51^{\circ} \mathrm{C} \quad 25^{\circ} \mathrm{C}$
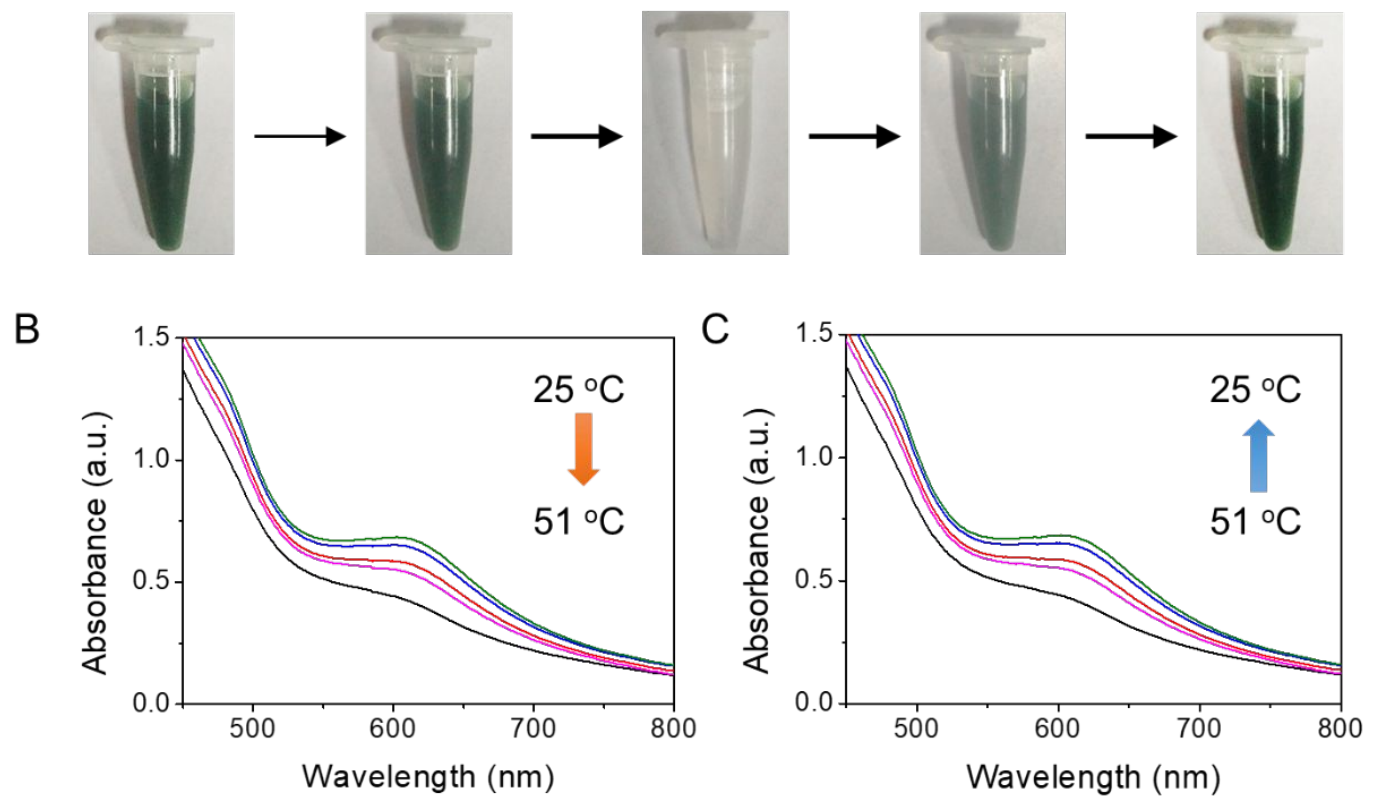

Figure S4. Reversible thermochromism of the TFG/BPA NPs. (a) Digital images showing the thermochromic behavior of the TFG/BPA NPs solution (at TFG dose of $400 \mu \mathrm{g} \mathrm{mL}^{-1}$ ) within the temperature range of $25-51{ }^{\circ} \mathrm{C}$. The UV-vis absorption spectra of TFG/BPA NPs solution (at TFG dose of $50 \mu \mathrm{g} \mathrm{mL}^{-1}$ ) during the heating (b) and cooling (c). 


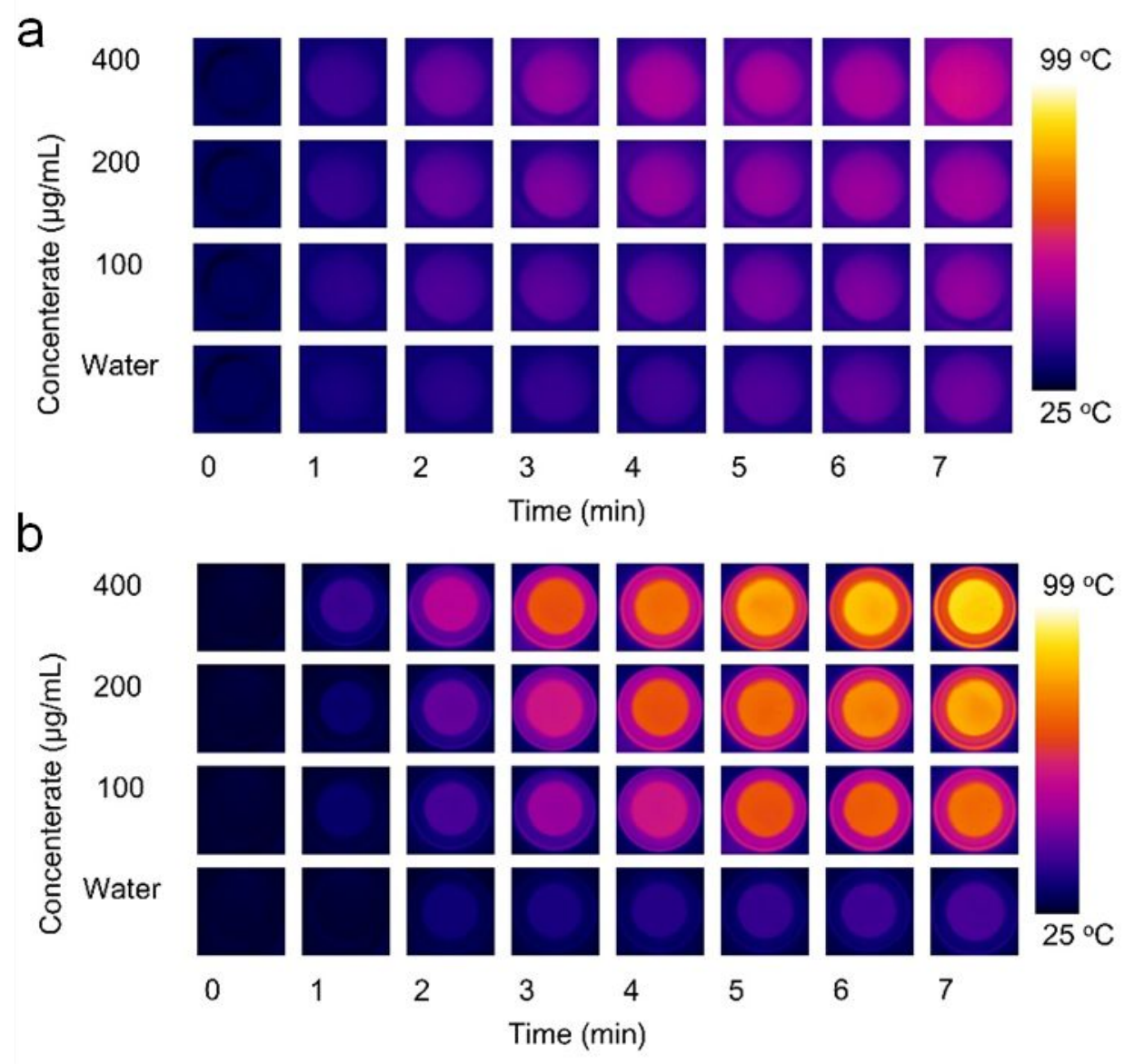

Figure S5. Infrared thermal images of TFG/Naph NPs (a) and ICG (b) with different concentrations $\left(100,200,400 \mu \mathrm{g} \mathrm{mL}^{-1}\right)$ under irradiation of NIR laser $\left(2 \mathrm{~W} \mathrm{~cm}^{-2}\right)$. 


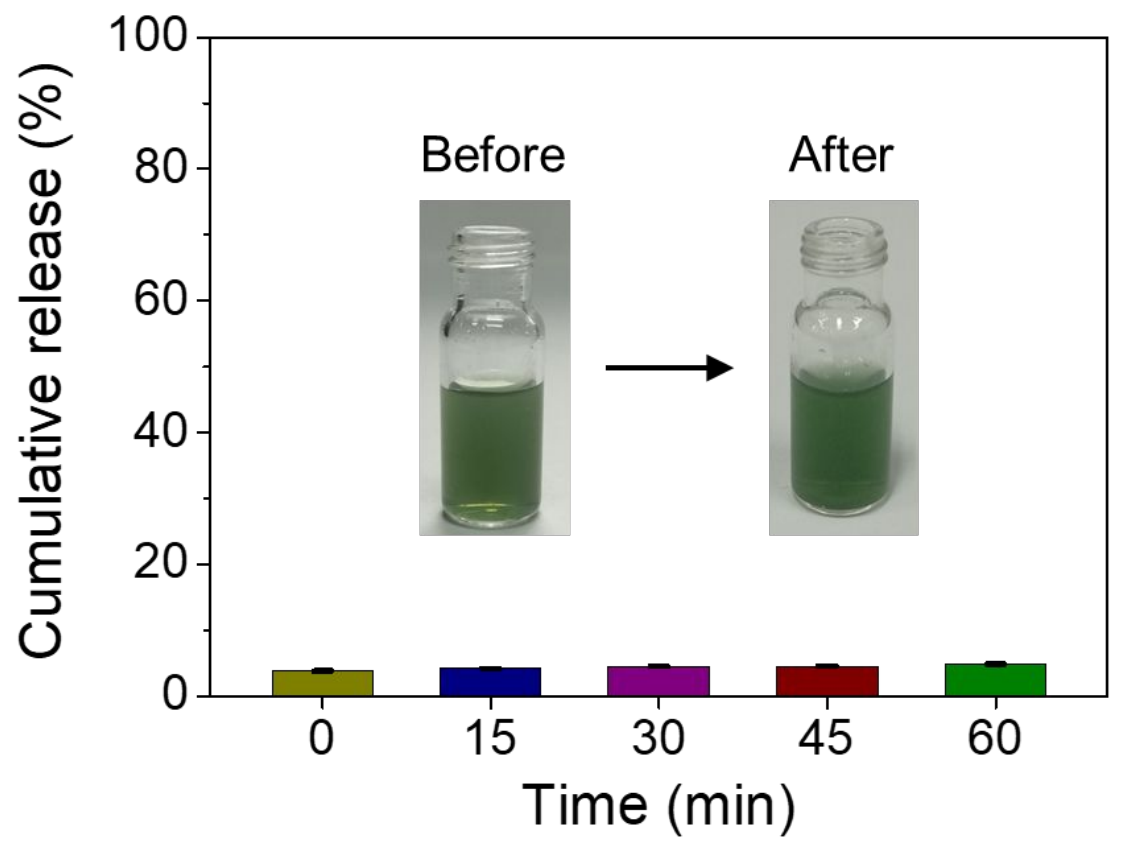

Figure S6. The appearance and cumulative release of TFG from TFG/Naph NPs during heating for $60 \mathrm{~min}$. 
a

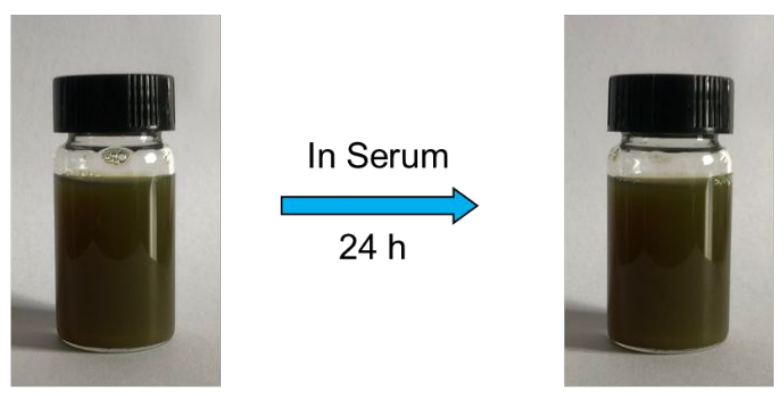

b
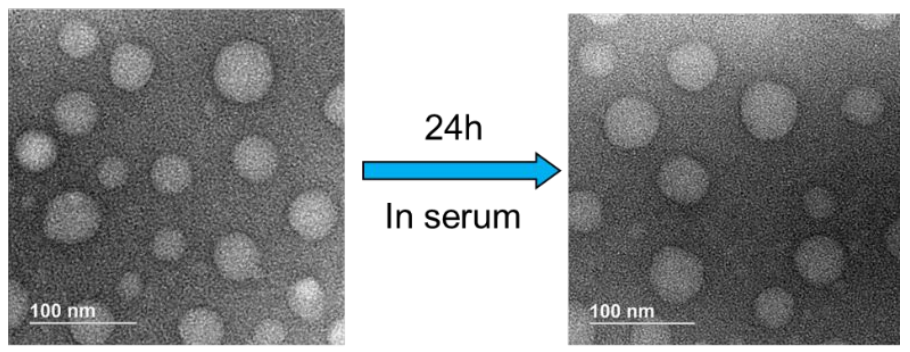

Before incubation

Figure S7. The stability of TFG/Naph NPs in serum. Digital images (a) and TEM images (b) of TFG/Naph NPs before and after dispersion in serum for $24 \mathrm{~h}$. 


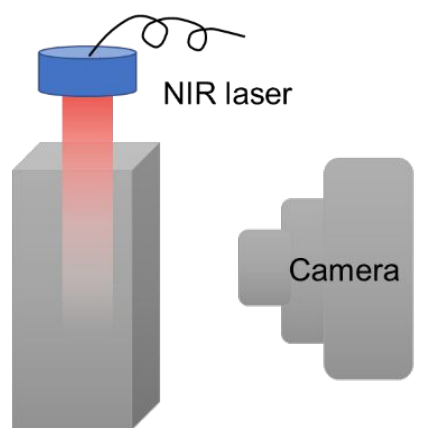

Figure S8. Schematic diagram of the device for determination of light penetration. 


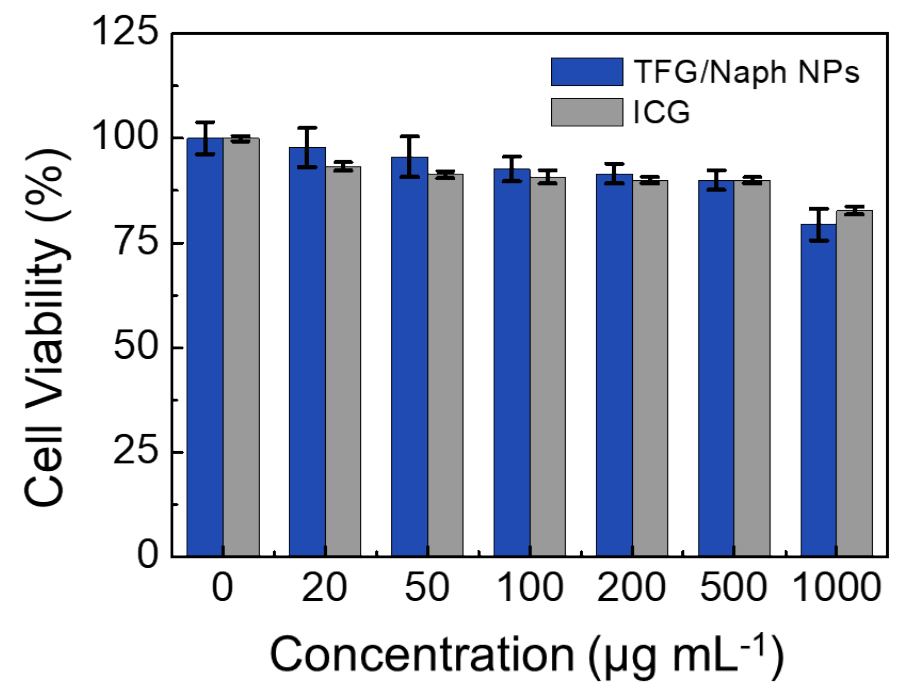

Figure S9. Cell viability of MCF-7 cells after incubation with TFG/Naph NPs and ICG at different concentrations for $24 \mathrm{~h}$ without the irradiation of NIR laser. The data points were represented as mean $\pm \mathrm{SD}(\mathrm{n}=6)$. 

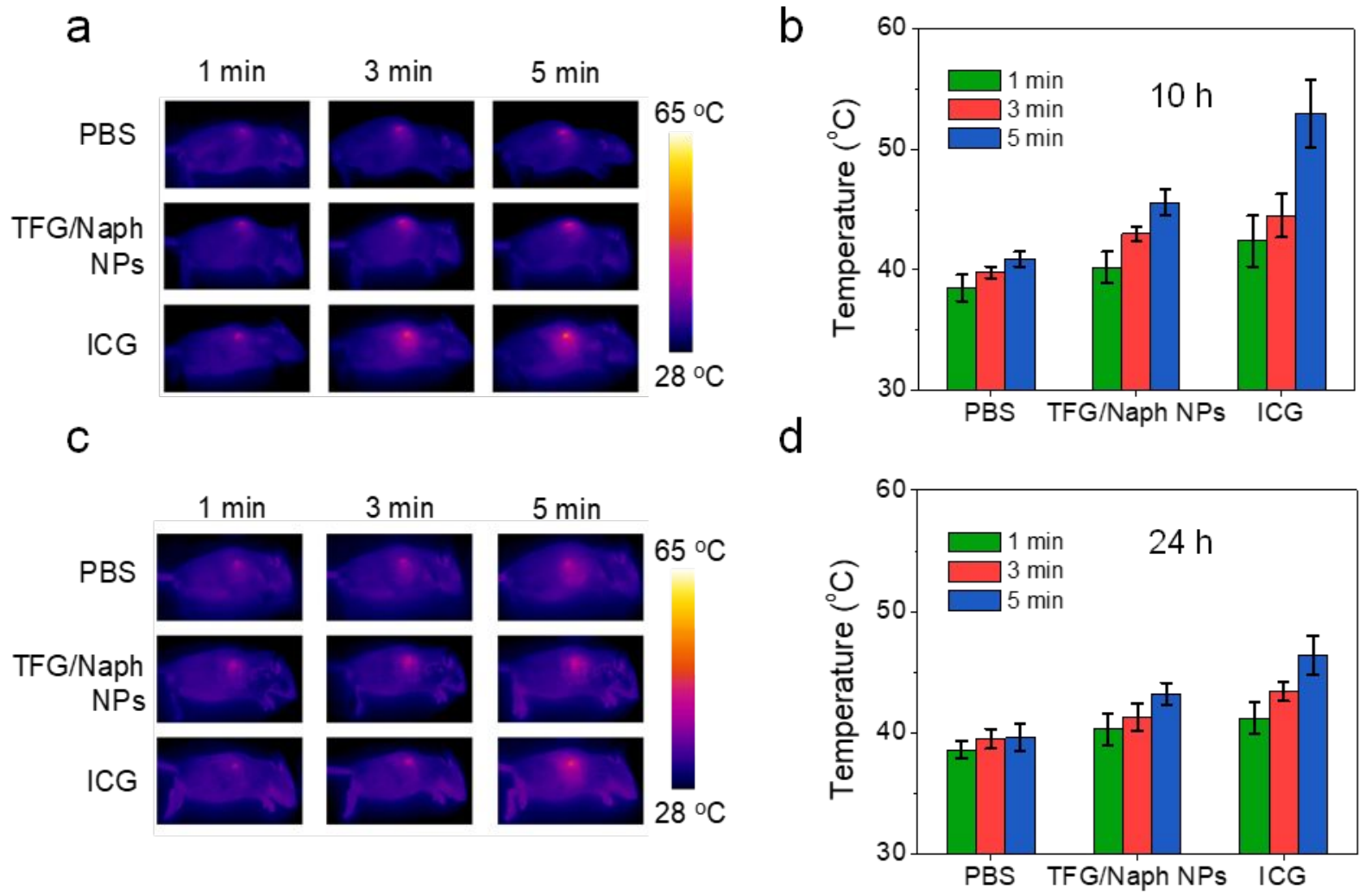

Figure S10. Tumor temperature after NIR irradiation. Thermographic images of tumor-bearing mice after intravenous injection of PBS (200 $\mu \mathrm{L}), \mathrm{TFG} / \mathrm{Naph}$ NPs (200 $\mu \mathrm{L}$, at a dose of $4 \mathrm{mg} \mathrm{kg}^{-1}$ of TFG), and ICG (200 $\left.\mu \mathrm{L}, 4 \mathrm{mg} \mathrm{kg}^{-1}\right)$ for $10 \mathrm{~h}$ (a), $24 \mathrm{~h}$ (c) and irradiation of NIR laser at a power density of $2 \mathrm{~W} \mathrm{~cm}^{-2}$ for $1 \mathrm{~min}, 3 \mathrm{~min}$ and $5 \mathrm{~min}$. The corresponding temperature during the irradiation after injection for $10 \mathrm{~h} \mathrm{(b)}$ and $24 \mathrm{~h} \mathrm{(d)}$. 


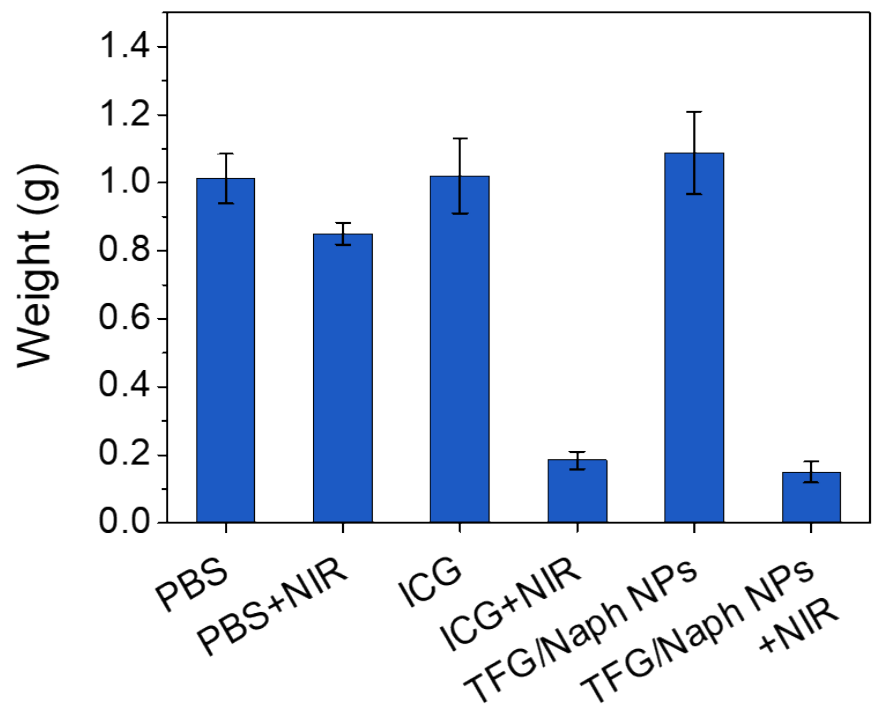

Figure S11. Average weights of tumors at the end of 14 days treatment. The data points were represented as mean $\pm \mathrm{SD}(\mathrm{n}=3)$. 


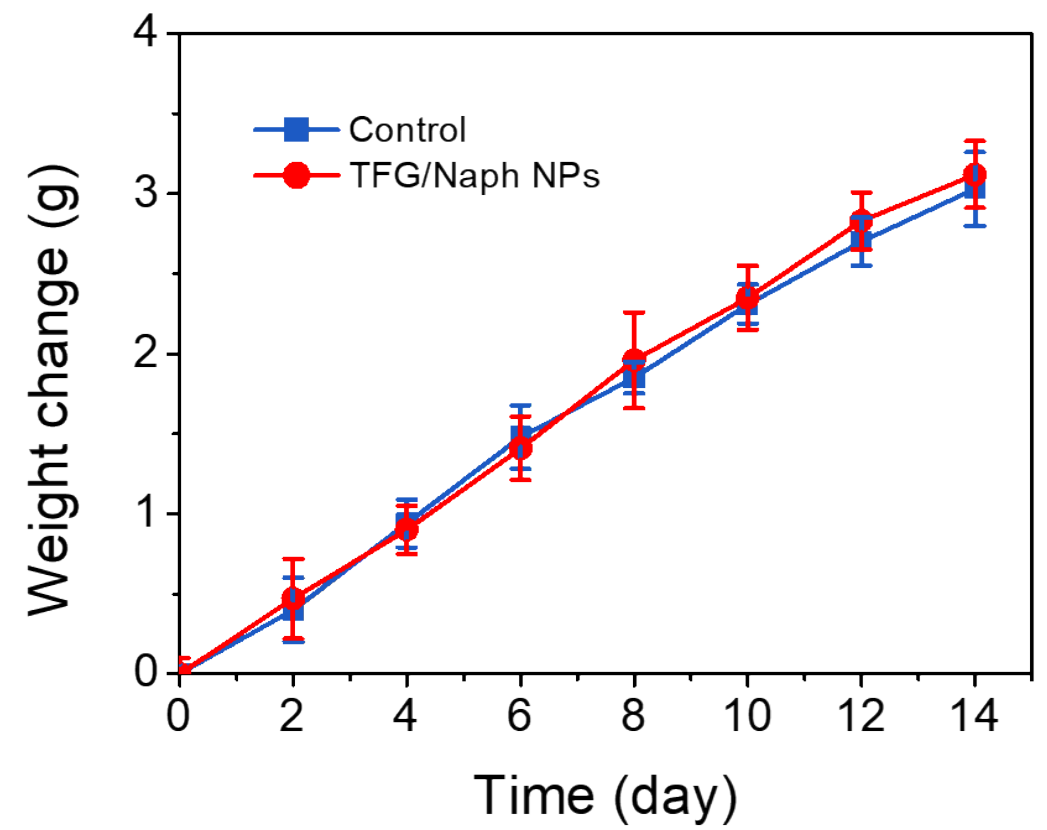

Figure S12 Weight changes of the mice after different treatments. The data points were represented as mean $\pm \mathrm{SD}(\mathrm{n}=3)$. 


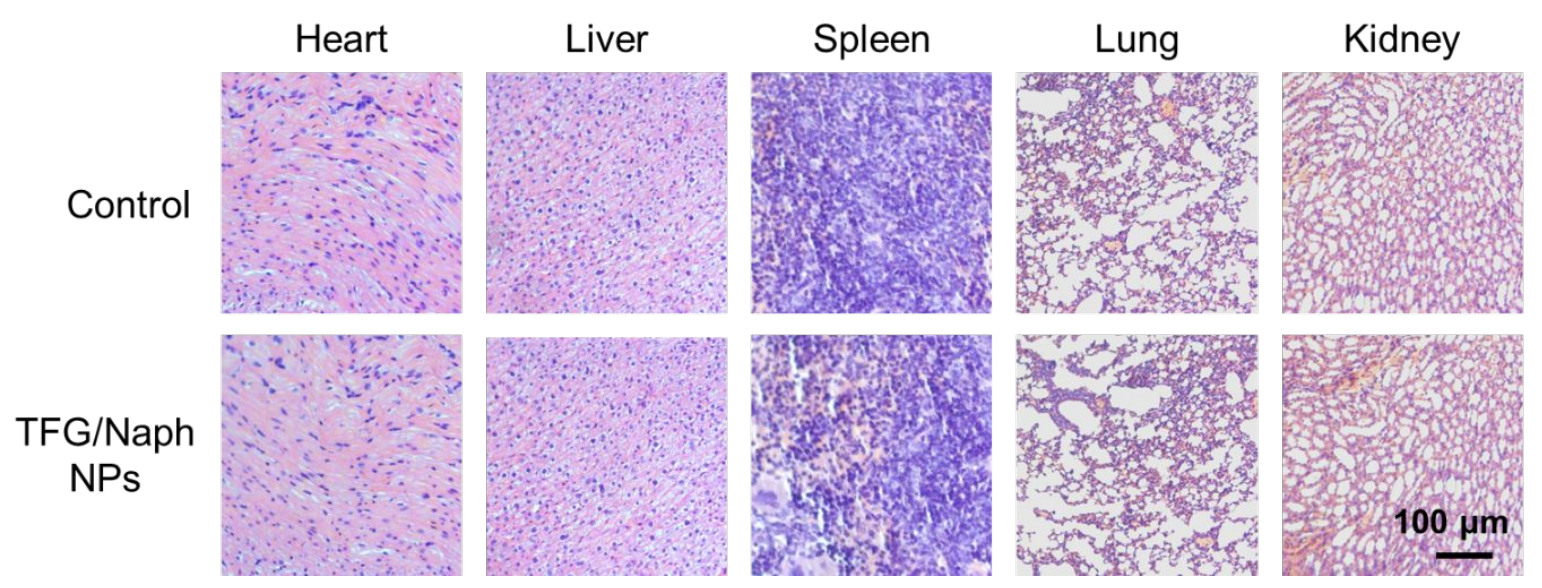

Figure S13. H\&E stained histologic sections of the heart, liver, spleen, lung and kidney after injection of TFG/Naph NPs for 14 days. 